\title{
Overview of Beneficiation, Utilization and Environmental Issues in Relation to Coal Processing
}

\author{
B K MISHRA*, B DAS, S K BISWAL and P S R REDDY \\ CSIR-Institute of Minerals \& Materials Technology, Bhubaneswar 751 013, Odisha, India
}

(Received on 26 April 2014; Accepted on 02 August 2015)

\begin{abstract}
In this overview, a brief description of Indian coal characteristic is presented. Based on the current production and looking at the future demands, beneficiation of Indian coal is emphasized. Two relevant case studies dealing with coal beneficiation are discussed. These studies show that low grade coal with $10 \%$ ash could be achieved by detailed characterization and beneficiation. The relevant issues dealing with various technological options such as selective mining, fine coal processing, dewatering, dry beneficiation, blending, coal to coke conversion, etc., are discussed. Finally, some of the environmental issues affecting future technology scenario are highlighted.
\end{abstract}

Keywords: Coal Maceral; Coal Utilization; Beneficiation; Dewatering; Blending

\section{Introduction}

Coal is considered as an energy mineral, and it is the most abundant source of fossil fuel energy in the world. It will continue to play a major role in economic development of India with particular reference to metallurgical and energy sectors. The bulk of the coal produced in India is thermal coal, which is primarily used for power generation. It provides $60 \%$ of the nation's electricity (Future of coal, 2013). The significant resources of coal in comparison to other fossil fuels have enabled this valuable mineral to remain at the centre stage of India's energy scene. Commercial energy consumption in India has grown from a level of about $30 \%$ to $60 \%$ of total energy requirement in the last four decades. It has grown at a rate of $7.2 \%$ during the last two decades as against the world average of only $2.2 \%$ (B.P. Statistical Review, 2013). Today, there are several conceivable problems associated with coal and the main one is that traditional technologies used for the generation of electricity from coal give rise to serious environmental concerns such as emissions of NOx, $\mathrm{SO}_{\mathrm{x}}$ and $\mathrm{CO}_{2}$. The development and deployment of technologies for zero-emission power generation from coal is thus a necessary condition in a $\mathrm{CO}_{2}{ }^{-}$ constrained world (Trombley and Kissock, 2007). The sooner we understand this aspect, the sooner we will be able to mitigate the problem.

Reserves of coal are more evenly distributed across the world and therefore it can be procured from a number of countries practically from all continents. It is pertinent to mention that reserves of hard coal are equivalent to about 255 years of production at the present rate and the reserves of lignite may last for about 130 years of present production. In contrast, the estimated reserves of oil and natural gas are expected to last for 40 and 65 years, respectively, at the current rate of production (Iwaro and Mwasha, 2010).

The total geological reserve of coal in India is about $287 \mathrm{Bt}$ (billion ton) as on $1^{\text {st }}$ January 2013. Coking and non-coking coal resources of India are given in Table 1 (The energy policy, 2015). The total coking coal reserve is only $32.3 \mathrm{Bt}$ as against $222.9 \mathrm{Bt}$ of non-coking coal. This indicates that India has acute

*Author for Correspondence: E-mail: bkm@immt.res.in,dir@immt.res.in; Tel: +91-674-256-7126, +91-674-237-9401 
Table 1: Coking and non-coking coal resources of India

\begin{tabular}{ll}
\hline Types of coal & Estimated reserve in Bt \\
\hline Coking: & \\
Prime coking & 5.4 \\
Medium coking & 25.3 \\
Semi-coking & 1.7 \\
Sub-total coking & 32.3 \\
Non-coking & 222.9 \\
Total (Coking and non-coking) & 257.6 \\
\hline
\end{tabular}

shortage of coking coal reserves and as a result there is an increasing trend of imports every year for metallurgical purposes. Around $90 \%$ of coal reserves come under non-coking coal category. Most of the coal reserves in India are of low quality and drift origin. These are difficult to wash because of intermixing of coal and inerts (both macerals and mineral matters) resulting from geological phenomena typical to Indian coals of Gondwana origin. The quality of coal is further deteriorated due to mechanized bulk mining and exploitation of poor quality seams. Most of the noncoking coals have high ash content varying from 40$55 \%$ with high near-gravity materials. As a result, this coal has poor washability character. Washability refers to theoretical potential of clean coal at particular ash content. The demand of coal is increasing dayby-day - it was $474 \mathrm{Mt}$ (million ton) in the 2006-07 but the indigenous coal production was $434 \mathrm{Mt}$ and the balance amount of $40 \mathrm{Mt}$ was met via import. The demand for coal by power sector for 2011-12 has been pegged at around $730 \mathrm{Mt}$ but the production target for the same period is at around $680 \mathrm{Mt}$. The Planning Commission of India has estimated that the country's coal demand to go up to $1000 \mathrm{Mt}$ by the end of the 12 $2^{\text {th }}$ Plan period (2012-2017), and the import of coal may exceed over $200 \mathrm{Mt}$. Due to less production and higher demand of coking coal, India's coal imports is increasing every year and it has reached $101 \mathrm{Mt}$ in 2012. Clearly, coal in the Indian context is the most secure and abundant fossil fuel and as such, its inclusion in the energy mix offers benefits in terms of energy security.
Most of the coal produced in India is high in ash with low useful heat value. Therefore, one critical issue that would control large-scale utilization of our coal is environmental pollution. In order to utilize coal in an environment-friendly way and to improve coal utilization efficiency, it is imperative that clean coal technologies such as integrated gasification and combined cycle (IGCC), the pressurized bed combustor (PBC) combined cycle, etc., are adopted. These technologies require cleaning of thermal coals, coal-water slurry preparation, underground coal gasification, carbon and $\mathrm{CH}_{4}$ capture, etc. For this purpose, the most advanced characterization technique and beneficiation practice must be developed. It would then be possible to develop strategies and systems for coal upgrading and feed preparation for emerging clean coal technologies. Here, we discuss results of our research on characterization of coking and noncoking coal focusing on structure, macerals, petrography, etc., along with some case studies on beneficiation.

\section{Coal Characteristics}

Coal is a special type of rock - it is a sedimentary rock composed of organic carbonaceous matter macerals and inorganic minerals. The coal has different constituents that can be measured in a laboratory which include proximate and ultimate analyses involving fixed carbon, volatile matter, moisture, and ash percentages. The different types of coal and its use in different sectors are shown in Fig. 1. The various coal types recognized principally by differences in volatile matter and $\mathrm{H} / \mathrm{C}$ atomic ratio are progressively eliminated from bituminous to anthracite ranks. The grade of low rank coals is

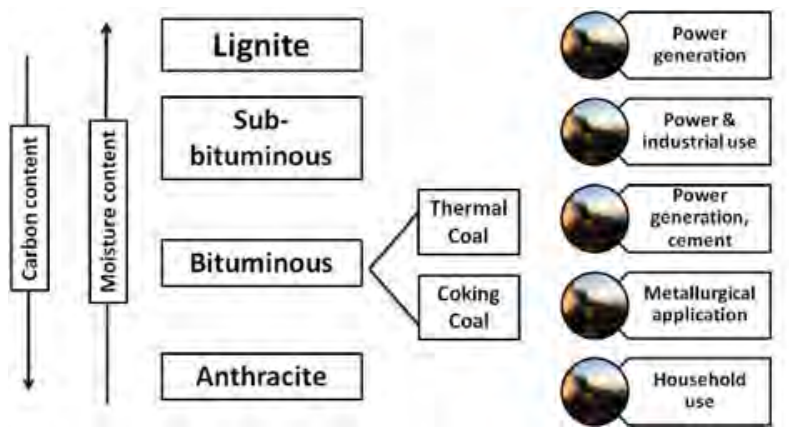

Fig. 1: Types of coal and its utility 
usually very low and limited to power generation. The major problem of utilization of low rank coals is linked to high moisture and high ash content. Drying, cleaning and blending prior to the use of low-grade coal are essential.

\section{Coal Structure}

Coal is a naturally occurring combustible solid. Geologists believe that coal deposits were formed about 250-300 million years ago due to degradation of plants and trees over a period of million years. Coal is predominately carbon and hydrogen with various impurities of different elements. According to rank, there are four types of coal: lignite, subbituminous, bituminous and anthracite. The carbon content of coal ranges from $40 \%$ for lignite to about $98 \%$ for anthracite. Coals of different varieties have different chemical compositions, and therefore different structures. Even within a certain rank of coal such as lignites or bituminous coals, the structure may vary depending on the environment in which a particular coal is formed. It has a high molecular weight, much higher than that of natural gas or petroleum. A natural gas is mostly methane with a molecular weight of 16 and that of octane with a molecular weight of 114. Coal is somewhat similar to mixture of many aliphatic and aromatic compounds and can be treated as a polymer of many such compounds. Basically, it consists of large heterocyclic monomers, held together by the three-dimensional C$\mathrm{C}$ groups. A typical structure of coal is shown in Fig. 2 , where the carbon atoms are arranged in an aromatic structure (Mathews and Chaffee, 2012). Simple aliphatic and alicyclic hydrocarbon groups predominate the coal structure. However, on the surface, there are many groups such as phenol, alcohol, aldehydes, etc. From a practical standpoint, it is important to

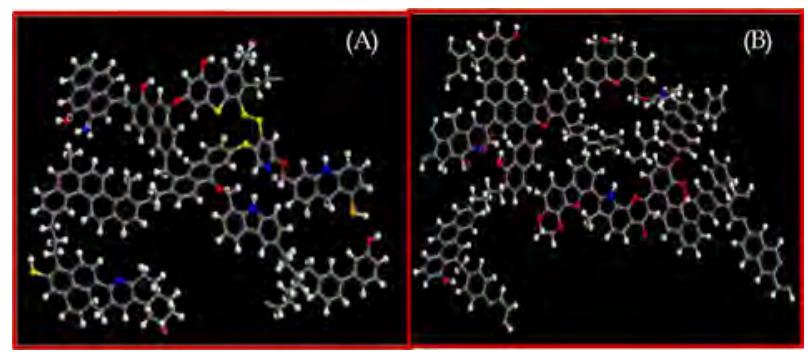

Fig. 2: Example of coal structure recognize oxidation of coal that involves transformation of surface groups leading to poor flotation performance.

\section{Mineral Matters}

Coal consists of two classes of material: organic components or macerals, and a range of minerals and other inorganic constituents, broadly referred to as "mineral matter". Thus, mineral matter represents the mineralogical phases as well as other inorganic elements in coal. After burning, the residue of mineral matter is termed as ash. The quality and quantity of ash depend upon type and rank of coal. Mineral matters vary widely in coal seams. The amount, mode of occurrence, and composition of the mineral matter in coal are factors of great practical importance in determining its market acceptability and economic value. The yields and qualities of products obtainable by cleaning the coal are also dependent upon the characteristics of mineral matter. According to its mode of origin, mineral matter within a coal seam may be classified into the following two categories: inherent and extraneous mineral matter. Inherent mineral matter cannot be separated from coal by simple washing while extraneous mineral matter can be removed from coal.

\section{Macerals}

Macerals are the various organic components that make up coal and control its overall behaviour. These are the descriptive equivalent of minerals which are the inorganic components of rocks. It can be considered as the organic part of coal having distinct physical and chemical properties. The macerals are of three major groups: liptinite, vitrinite and inertinite. The liptinite group is derived from the waxy and resinous parts of plants. The vitrinite group is derived from coalified woody tissue. The inertinite group is derived from woody tissue that has been altered by fire or biochemical processes. The major inertinite macerals are fusinite and semifusinite derived, respectively from coalified charcoal and semicharcoal. The order of reactivity of macerals is as follows: vitrinite>inertinite>liptinite (exinite). Most of the maceral characterization has been performed in situ with petrographic methods. 


\section{Petrography}

Coal petrography provides detailed description and identification of different macerals present in coal (Crelling, 2008). It uses reflected light microscopy and polished sections of the material being studied. It has various applications in the field of coal characterization, carbonization, combustion, beneficiation, etc. Here, we provide an example of Hingula coal of Talcher area (Report, 2015). The macerals can be determined on volume basis or volatile and mineral material-free (vmmf) basis. It has been observed that the vitrinite macerals dominate in Hingula coal with $38 \%$ by volume ( $49 \%$ vmmf). It shows flat surfaces and appears as grey in colour. Oxidized vitrinite is found in significant amount up to $12 \%$ (16\% vmmf) showing oxidation cracks. Inertinites are dominated by semi fusinites with small cellular cavities. The fusinites show prominent cell cavities and bright colour. Inertodetrinites appear as bright fragmental form and contribute up to $19 \%$ by volume ( $25 \%$ vmmf). Liptinite macerals occur with thread-like dark appearance up to $8 \%$ by volume $(10 \%$ vmmf). Mineral matter (mainly the argillites and carbonate minerals) occur as dark colour either in cavity filling form or in disseminated form contributing upto $23 \%$ by volume. The macerals constituents are provided in Table 2 . The gross calorific value of the coal was found to be $4535 \mathrm{kcal} / \mathrm{kg}$. A micrograph showing oxidized vitrinite with mineral matter is shown in Fig. 3.

\section{Beneficiation}

\section{Coking Coal}

Beneficiation of coking coal in India is being practised by Coal India Ltd., SAIL and Tata Steel. The total

Table 2: Maceral constituents of Hingula coal of Talcher coal belt

\begin{tabular}{lcc}
\hline Petrographic constituents & Vol. \% basis & Vmmf basis \\
\hline Normal vitrinite & 38 & 49 \\
Vitrinite oxidized & 12 & 16 \\
Inertinite & 19 & 25 \\
Liptinite & 8 & 10 \\
\hline
\end{tabular}

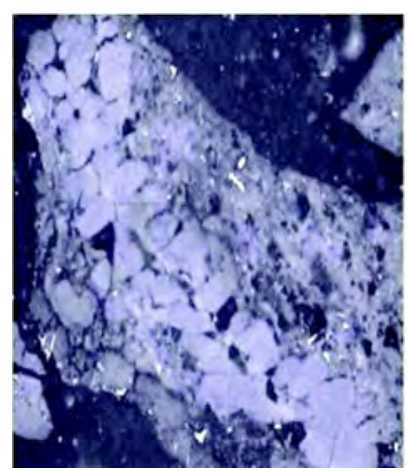

A

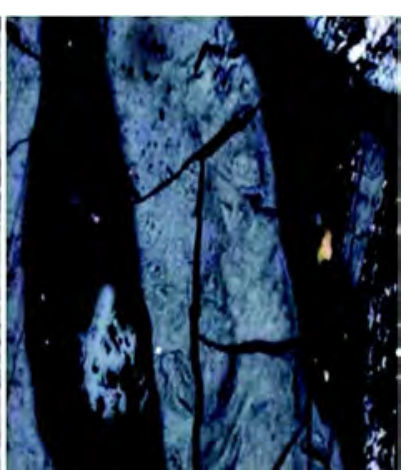

B
Fig. 3: A: Micrograph of oxidized vitrinite with oxidation cracks and mineral matter under reflected light and B: Micrograph of oxidized vitrinite with mineral matter and inertodetrinite under reflected light

production of coking coal in India is approximately 18-19 Mt per annum. The shortfall is more than 25 Mt per annum which is being imported. The ash content in run-of-mines coking coal is as high as 30$45 \%$. Presently, the coal is being supplied to steel plants after beneficiation in washeries. At present, the cut-off ash level for coke making is between $13 \%$ and $18 \%$ depending on the coal characteristics and available equipment facility in the washery. In coking coal washery, heavy media cyclone, jig, and flotation processes are used for beneficiation (Das et al., 2008 a; Cloke et al., 1997; Atesok, et al., 1993; Singh and Das 2013). In heavy media circuits, coal is crushed to below $13 \mathrm{~mm}$ size and classified at $0.5 \mathrm{~mm}$ size. The $-13+0.5 \mathrm{~mm}$ size fraction is treated in heavy media circuit. In this circuit, concentrate, middling, and tailings are generated in two-stage heavy media cyclone processes. Good amount of middling is generated in this process because of the high percentage of neargravity materials in the coal. Mostly, this middling is used for power generation. Depending on the feed quality of coal, tailings are also used for power generation. In heavy media circuit, special grade magnetite is used to control the density of separation. Magnetite as the media plays a vital role in reduction of misplacement materials. The Fe value of magnetite should be high $(71-72 \% \mathrm{Fe})$ and particle size distribution be such that $-45+30 \mathrm{~mm}$ fraction and -30 $\mathrm{mm}$ fraction should be $85 \%$ and $15 \%$, respectively. This concept has been successfully tested by Tata Steel in West Bokaro washery to improve the 
separation efficiency of heavy media cyclone. The heavy media circuit generates $-0.5 \mathrm{~mm}$ size fraction which is beneficiated by flotation process. Till today, conventional flotation circuit is being practised to recover carbon values in desired quality. The overall performance of flotation cell is not up to the desired level and as a result a good amount of coal is lost in flotation tailings. It can be improved further in flotation circuit by adopting advance column flotation technology (Hacifazlioglu, 2012; Jena et al., 2008).

Many washeries do not get the desired yield due to change in characteristics of coal. For this reason, $\mathrm{R} \& \mathrm{D}$ organizations in India are working towards reducing the ash content by suitable beneficiation strategies. Although there is successful reduction of ash content in case of foreign coals by the adoption of advanced techniques, the same may not be applicable to Indian coal due to varying nature and association of carbonaceous and ash materials in it. The technology as adopted for USA, Australia, Brazil, Germany, and other countries for coking coal beneficiation, cannot be adopted directly for Indian coal. Due to the unique character of Indian coal, it is necessary to make modification to the existing technology or develop new equipment suitable for beneficiation of Indian coal to reduce the ash content to around $10 \%$.

\section{Non-coking Coal}

Beneficiation of non-coking coal in India was not given due importance till 2000 or so, due to its low calorific value and lower cost competitiveness. However, realizing the low useful heat value of non-coking coal coupled with stringent environmental requirements with respect to ash generation, many coal industries in India are forced to set up non-coking coal washeries. Few washeries have been set up to beneficiate non-coking coal by Coal India and private agencies at different places (having total capacity of around 100 million tons per annum). The coarser size fractions are beneficiated using jig, heavy media bath, and heavy media cyclone. In most of the cases, the fine coal (below $1 \mathrm{~mm}$ size) is not being processed and it is either rejected or partly utilized by blending with beneficiated coal based on the ash content. In some of the non-coking coal washeries, below $1 \mathrm{~mm}$ size fraction is classified by hydrocyclone and the undersize is used in power plants after dewatering and the hydrocyclone overflow is rejected directly to the tailings pond. The underflow of hydrocyclone is further treated in specific cases by spiral concentrators to improve the quality. The ash content in these fines varies from $45-55 \%$ depending on the input ash of the washery. It contains good amount of ultra fine clay minerals, which cannot be dewatered by currently available dewatering technology. It creates many environmental problems in the surrounding areas of the washery. The generation of this fine is quite high due to banded formation of coal seam. The quantum of this ultrafine coal from the washery typically ranges from $5 \%$ to $7 \%$ of feed coal. As it is fine in nature, gravity technique cannot be utilized. The flotation technique is required to upgrade this ultra fine nature of coal. However, surface of non-coking coal always gets oxidized when it is exposed to the oxygen atmosphere. As a result, the floatability characteristic of coal decreases. To improve the floatability, pre-treatment is needed before flotation. The overflow of the hydrocyclone, i.e. the washery tailings should be beneficiated by a combination of physical/chemical/biological processes. The combination of many advanced techniques to achieve quality clean coal is the prime objective for efficient productivity of the user industries. There are several attempts being carried out to beneficiate the noncoking coal in India. It is observed that in most of cases, the ash could be reduced to $15-17 \%$ from as high as 40\% ash (Dey et al., 2013; Panda et al., 2012; Dwari and Hanumantha Rao, 2006; Mathur et al., 2003; Xia et al., 2013).

\section{Case Study I: Quality enhancement of coal for its effective utilization}

\section{Non-coking Coal}

Under $10^{\text {th }}$ five year plan, CSIR undertook an extensive characterization and beneficiation studies on different coal samples from India representing all types of coals to evaluate their quality and to prepare strategies for their effective utilization. These studies include detailed characterization, washability, and 
beneficiation studies to reduce the ash content. Several different coal samples from Mahanadi, Eastern, Central and South-east coal fields were studied. The main characteristics of coal samples are presented in Table 3. The washability characteristics of different coals are given in Table 4 (Report, 2015). It is observed that the washed fraction of Rajmahal, Kalinga, and Religarah coals show better burnout than their unwashed fractions. However, the washed fractions of Chitra coal show a different trend. Blending studies (which is discussed later) show that a significant proportion of the low volatile matter high rank coal can be blended with the low-ranklow-ash coal for achieving good burnout.

Table 3: Characteristics of coal samples

\begin{tabular}{lcccc}
\hline Origin of coal & $\begin{array}{c}\text { Ash } \\
\%\end{array}$ & $\begin{array}{c}\text { Moisture } \\
\%\end{array}$ & $\begin{array}{c}\text { Volatile } \\
\text { matter } \\
\%\end{array}$ & $\begin{array}{c}\text { Ash fusion } \\
\text { temperature } \\
{ }^{\circ} \mathrm{C}\end{array}$ \\
\hline MCL & $35-50$ & $5.0-7.0$ & $27.0-45.0$ & $1200-1400$ \\
ECL & $36-48$ & $2.6-8.3$ & $38.5-40.0$ & $1280-1400$ \\
CCL & $24-30$ & $2.0-3.0$ & $37.7-40.0$ & - \\
SECL & $34-36$ & $6.5-9.0$ & $26.0-27.0$ & - \\
\hline
\end{tabular}

Table 4: Washability characteristics of coal samples

\begin{tabular}{|c|c|c|c|c|}
\hline \multirow{2}{*}{$\begin{array}{l}\text { Details } \\
\text { of coal } \\
\text { samples }\end{array}$} & \multicolumn{2}{|c|}{$\begin{array}{l}\text { Washability } \\
\text { characteristics }\end{array}$} & \multirow{2}{*}{$\begin{array}{l}\text { Utilization } \\
\text { pattern }\end{array}$} & \multirow{2}{*}{$\begin{array}{l}\text { Techniques adopted } \\
\text { and response to } \\
\text { beneficiation }\end{array}$} \\
\hline & Ash \% & Yield \% & & \\
\hline MCL & $\begin{array}{l}34.0 \\
25.0\end{array}$ & $\begin{array}{c}86.0 \\
53.0-60.0\end{array}$ & $\begin{array}{l}\text { Good for } \\
\text { power } \\
\text { generation }\end{array}$ & $\begin{array}{l}\text { Jig/HM cyclone. } \\
\text { Clean coal with } \\
25.0 \% \text { ash for } \\
\text { sponge iron can be } \\
\text { produced }\end{array}$ \\
\hline ECL & $\begin{array}{l}34.0 \\
25.0\end{array}$ & $\begin{array}{l}58.0-92.0 \\
30.0-80.0\end{array}$ & -do- & $\begin{array}{l}\mathrm{Jig} / \mathrm{HM} \text { separation } \\
\text { to produce clean coa } \\
\text { for sponge iron }\end{array}$ \\
\hline $\mathrm{CCS}$ & 25.0 & 84.0 & -do- & $\begin{array}{l}\text { Heavy media } \\
\text { separation: Clean coa } \\
\text { with } 25.0 \% \text { ash for } \\
\text { direct reduction }\end{array}$ \\
\hline SECL & $\begin{array}{l}34.0 \\
31.0\end{array}$ & $\begin{array}{c}25.0 \\
13.30\end{array}$ & -do- & $\begin{array}{l}\text { Heavy media } \\
\text { separation: Clean coa } \\
\text { with } 34.0 \% \text { and } \\
26.0 \% \text { for direct } \\
\text { reduction and power } \\
\text { generation }\end{array}$ \\
\hline
\end{tabular}

\section{Coking Coal}

Characteristics of the lower seam coals of the Jharia Coalfields and West Bokaro Coalfields show high ash percent, low volatile matter and poor coking property. Washability studies on the raw coal crushed to 75 $\mathrm{mm}$ showed poor washability characteristics and the theoretical yield for steel grade coal is considerably low. The washing scheme developed for the treatment of coals from the lower seams of Eastern part of Jharia Coalfields may not be applicable to the coal of western part. Moreover, clean coal for metallurgical industries and power plants may not be generated simultaneously. Application of computer simulation on washability data for prediction of achievable power grade coal from coarser fraction and steel grade coal from finer fractions yielded the following results (Mohanta et al., 2010). Muraidih OCP coals: $12.0 \%$ yield at $17.5 \%$ ash level (steel grade) $19.5 \%$ yield at $34.2 \%$ ash level (power plant grade) and $67.6 \%$ yield at $56.1 \%$ ash (FBC); Kuju OCP coals: $13.7 \%$ yield at $17.5 \%$ ash (steel grade) $60.1 \%$ yield at $34 \%$ ash (power plant grade) and $26.2 \%$ yield at $49.9 \%$ ash (FBC). Investigations were also carried out on fine coal samples $(-0.5 \mathrm{~mm})$ generated at Patherdih,

Table 5: Comparison of characteristics of different coal fines

Details Patherdih Bhojudih Munidih Muraidih Muraidih (oxidized)

\begin{tabular}{lccccc}
\hline \multicolumn{5}{c}{ (a) Ash \% } \\
& 34.3 & 25.8 & 22.1 & 32.0 & 40.4 \\
& & (b) Size Analysis & \\
+500 & 27.2 & 8.8 & 10.3 & 0.5 & 1.2 \\
+300 & 20.4 & 8.1 & 7.3 & 24.2 & 41.1 \\
+150 & 18.8 & 12.5 & 8.2 & 15.9 & 14.6 \\
+75 & 18.1 & 15.7 & 6.0 & 7.9 & 13.1 \\
+45 & 9.3 & 5.3 & 16.3 & 10.4 & 7.8 \\
-45 & 6.2 & 49.5 & 51.9 & 41.1 & 22.2 \\
& & (c) Releave Analysis & & \\
Ash \% & & 14,4 & 14.1 & 15.2 & 14.7 \\
Yield \% & & 75.0 & 61.2 & 76.0 & 38.8 \\
\hline
\end{tabular}


Bhojudih, Munidih and Muraidih coking coal washeries. The physical and chemical characteristics are compared in Table 5 (Sastry et al., 1988). These studies indicate that the ash content of the samples varies from $22.0 \%$ to $40.4 \%$. The size analysis indicates that the fraction below 45 micron also varies widely ( $15.0 \%$ to as high as $68.0 \%)$. This indicates that the nature of these fines generated at different washeries varies widely. The recovery process needs to be tailor-made and each sample has to be investigated for all possible techniques to arrive at optimum technology to beneficiate these fines efficiently. In view of the above, all the samples were studies for release analysis, and flotation by cell and column. All the results are compared in Table 6. The results indicate that all the samples are amenable for beneficiation by flotation technique. These can be beneficiated by conventional cell or column to reduce the ash to below $17.0 \%$. These results indicate that flotation column technique yields superior performance compared to cell. Flotation column can yield better grade product (2-3\% less ash) for same yield or higher yield (5-10\%) at same ash level. However, these results need to be compared with the performance of advanced gravity units using combination of spirals and flotation, oil agglomeration, oleo flotation, etc., before selecting the optimum technique to enhance the performance of final coal recovery from these fines.

Table 6: Comparison of results of different coal fines

\begin{tabular}{lcccccc}
\hline & $\begin{array}{c}\text { Clean coal by } \\
\text { cell flotation }\end{array}$ & & $\begin{array}{c}\text { Clean coal by } \\
\text { column flotation }\end{array}$ & $\begin{array}{c}\text { Feed } \\
\text { ash \% }\end{array}$ \\
\cline { 2 - 3 } & Ash \% Yield \% & & \multicolumn{2}{c}{ Ash \% Yield \% } & \\
\hline A. Patherdih & 17.7 & 54.4 & & 14.34 & 60.8 & 34.3 \\
& 20.8 & 71.6 & & 17.40 & 76.5 & 34.3 \\
& 13.2 & 75.0 & & 9.0 & 61.1 & 25.8 \\
B. Bhojudih & 14.6 & 79.0 & & 12.0 & 68.0 & \\
& 14.1 & 87.3 & & 9.8 & 81.0 & 22.1 \\
C. Muraidih & 11.0 & 72.00 & & 5.0 & 52.0 & 22.1 \\
& 11.6 & 80.3 & & & & \\
D. Munidih & 14.0 & 71.4 & & 12.3 & 68.5 & 32.0 \\
(Oxidized) & 16.5 & 78.4 & & 9.7 & 51.0 & 32.0 \\
E. Muraidih & 18.8 & 42.0 & & 18.7 & 62.8 & 40.4 \\
\hline
\end{tabular}

\section{Case Study II: Beneficiation to Achieve 10\% Ash from High Ash Indian Coal}

Non-coking coal forms $90 \%$ of the total national coal reserve. The pattern of deposit of non-coking coal is in banded form. Depending on the thickness of the coaly bed, selective mining may be emphasized to achieve $25-30 \%$ ash coal. This coal can be further beneficiated using either jig or heavy media cyclone to achieve around $10 \%$ ash coal with reasonable yield. This category of mines may be preserved for utilization in metallurgical industries.

\section{Major Recommendations}

- Dry beneficiation studies of non-coking coals of India for power plants.

- Development of 3 or 2 product schemes to produce clean coal for sponge iron and cement industries by complete utilization.

- Identifying the coals suitable for sponge iron industry and increase the resource base for the above industries by suitable beneficiation.

- Technology to establish small capacity washeries for sponge iron and cement industries.

- Optimization and simulation of existing coking coal washeries to improve yield.

- Modernize the existing coking coal washeries by introducing advanced techniques.

- Development of suitable reagents for beneficiation of non-coking coal fines and oxidized coals.

The natural slimes generated during crushing of the coal for processing can be beneficiated by flotation process to produce two products with high ash rejects. In one of the products, it is possible to achieve $10 \%$ ash with $20 \%$ yield of total feed to the flotation circuit. This product can be used as coal fines for coal injection either in blast furnace or in DRI processes. Low volatile coking coal which has high ash and liberated below 100 micron size, can be utilized after flotation for coal injection in iron and steel industries after blending with low ash high volatile coal. The 
sulphur content in north-eastern states poses several problems for its utilization. By chemical and biological leaching process, sulphur reduction to the extent of $30-50 \%$ can be achieved. This coal after cleaning and sulphur removal can be used by blending with low sulphur coal. In contrast, the Talcher coal having negligible amount of sulphur can be cleaned effectively. A summary of results on a typical Mahandi coal field sample (Hingula of Talcher area) and a composite flowsheet is given in Table 7 and Fig. 4, respectively. In order to achieve $10 \%$ ash, the process flowsheet provided in Fig. 4 is tested in pilot scale using different equipment at a given particle size distribution. The result provided in Table 7 is reconciled with respect to $10 \%$ ash which gives $42 \%$ yield from a $26.38 \%$ feed ash.

\section{Technological Options}

\section{Fine Coal Processing}

As high-grade coals continue to decline, the role of flotation is likely to increase in future coal processing plant design schemes. In this context, column flotation technology assumes greater importance although the design and scale up of this technology is challenging. Issues such as bubble size, froth volume, dewatering, etc., must be carefully controlled for successful operation of columns. In an overall sense, circuit design and equipment selection are the key factors towards maximization of product quality and profitability. Agood circuit design-circuit type, parallel or series configuration, etc., ensures success of the operation. The selection of a flotation column requires a thorough understanding of coal quality and expected yield. This would allow proper designing of sparging

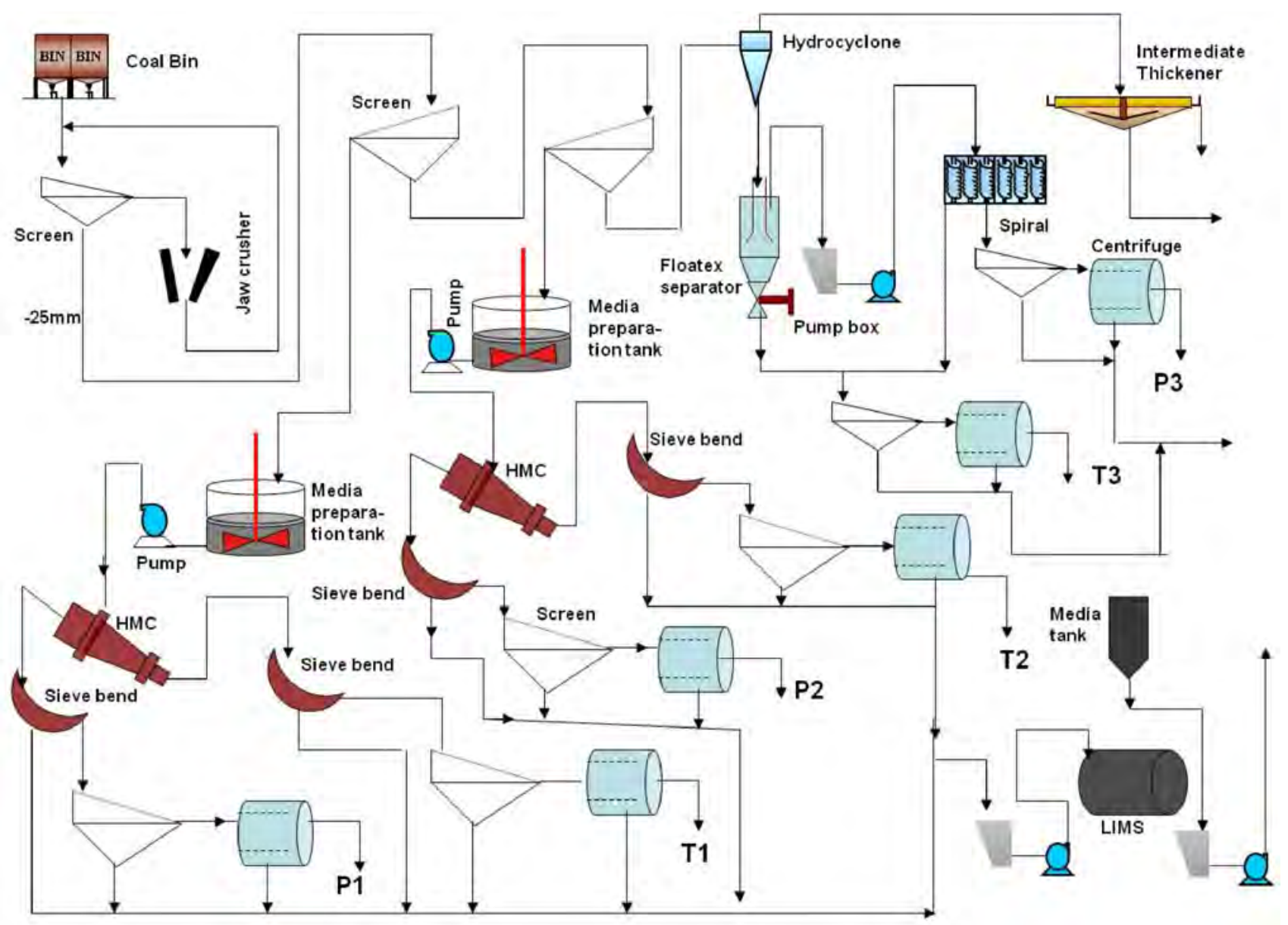

Fig. 4: Composite flowsheet for Hingula coal (P-Product, T-Tailings) 
Table 7: Beneficiation results of Hingula coal (Report 2015)

\begin{tabular}{|c|c|c|c|c|c|c|c|c|}
\hline \multirow[t]{2}{*}{ Size in $\mathrm{mm}$} & \multicolumn{2}{|c|}{ Feed } & \multicolumn{2}{|c|}{ Product } & \multicolumn{2}{|c|}{ Tails } & \multicolumn{2}{|c|}{ Total } \\
\hline & $\begin{array}{l}\text { Wt. } \\
\%\end{array}$ & $\begin{array}{c}\text { Ash } \\
\%\end{array}$ & $\begin{array}{l}\text { Wt. } \\
\%\end{array}$ & $\begin{array}{c}\text { Ash } \\
\%\end{array}$ & $\begin{array}{c}\text { Wt. } \\
\%\end{array}$ & $\begin{array}{c}\text { Ash } \\
\%\end{array}$ & $\begin{array}{c}\text { Wt. } \\
\%\end{array}$ & $\begin{array}{c}\text { Ash } \\
\%\end{array}$ \\
\hline$-25+6$ & 60.0 & 27.5 & 21 & 10 & 39 & 37 & 60 & 27.5 \\
\hline$-6+1$ & 18.0 & 25.0 & 8 & 10 & 7 & 40 & 15 & 24 \\
\hline$-1+0.1$ & 15.0 & 24.0 & 9 & 10 & 9 & 40 & 18 & 25 \\
\hline-0.1 & 7.0 & 25.0 & 4 & 10 & 3 & 45 & 7 & 25 \\
\hline Overall & 100 & 26.38 & 42 & 10 & 58 & 38.2 & 100 & 26.38 \\
\hline
\end{tabular}

technology, product carrying capacity, wash water input, and retention time. Available design criteria available in literature would provide adequate information for a successful flotation circuit design.

\section{Dewatering of Coal}

Dewatering is an unit operation integral to any wet coal beneficiation plant. The natural sedimentation rate of the particles present in colloidal and finely divided suspended form is very slow. At present, screen, centrifuge, and filter of various kinds are used for dewatering of coal concentrate. Tailings/slimes generated in coal washeries are disposed to tailings pond via thickener in the form of high concentration slurry. However, till today dewatering of slimes is not practised. In coal processing plants, a large volume of waste water containing a variety of solids are being generated. The amount of waste water is increasing year after year as a result of continuous mining and cleaning of coal in the coal industries. The increase of ultrafine particles and inorganic impurities in wastewater poses technical and economic difficulties in handling, settling of suspended particles, and recirculation of water into the plant. Fine coal processing is therefore, the most difficult and costly operation. For this reason, a suitable dewatering method is essential for dewatering the tailings slurry containing high clay content. The utilization of wastewater in coal washeries can be enhanced by dewatering of slimes using high pressure filter. Flocculation technology employing polymeric flocculants in conjunction with fine magnetite may be applied to achieve faster settling rate with lowest level of water turbidity (Das et al., 2008 b). The characteristics of washery reject water and proper choice polymeric flocculants is very much important. This of course depends on the chemical and physical characteristics of the pollutants present in the waste water.

\section{Dry Beneficiation}

Undoubtedly, wet processing of coal requires huge quantity of water. This provides enough incentive for dry beneficiation of coal which has great promise as a cleaning method, particularly from an environmental standpoint. There are different types of dry coal processes such as sorting, electrostatic separation, magnetic separation, and mechanical separation for dry coal beneficiation. These processes depend on the differences in physical properties between coal and gangue minerals such as density, size, shape, luster, magnetic conductivity, electrical conductivity, radioactivity, etc. Air dense medium fluidized bed separation process, pneumatic jig, and FGX are used commercially for beneficiation of coal on dry basis. Indian coals are not amenable to dry processing as most of the coal types are liberated at extremely fine sizes. Several studies carried out in India using heavy media fluidized bed separator and tribo-electric separator indicated that coal can be cleaned only up to $30 \%$ ash (Sahu et al., 2005; Dwari and Hanumantha Rao, 2008; Dwari et al., 2015). However, in recent years, much research effort is directed towards dry processing of fine coal particles in electrostatic separator which hold great potential to treat Indian coal. Advantages of the dry beneficiation are as follows:

- Reduction in process water requirement

- Reduction in water pollution due to effluent slurry

- Elimination of tailings pond

- Elimination of dewatering equipments

- Reduction in specific cost for transportation

\section{Blending}

In order to achieve the consistence coal quality, coal blending technique has been recognized as a well- 
accepted practice in coal washeries in India as well as abroad. Coal-blending techniques generally target one or more desired coal-blend quality such as size, ash, sulphur content, etc. However, this practice has shown that the behaviour of blends does not always comply with the expected weighted average value of parameters from the individual coals comprising the blend. Moreover, these changes in behaviour of the coal blend affect the downstream processing of the coal. Although a variety of simulation software is available, the simulated results do not agree well with the real-life plant operations due to variations in coal composition (Mohanta et al., 2012). It is a potential area for further research in an Indian context to induce a change in property of the coal blend than that of the individual coals. More importantly blending in an overall sense can have on effect on the performance of different downstream equipment.

\section{Non-Coking Coal for Coke Making}

Coking coals differ in their plasticity and fluidity properties from non-coking coals. Also these coals differ with respect to hydrogen content in their molecular structure. It is assumed that lack of hydrogen content leads to non-agglomerating behaviour of coal particles. Typically, coking coals have high hydrogen content of more than $5.5 \%$. Noncoking coals can be utilized for coke making by the following processes: (i) Hydrogenation of coal, (ii) Blending with high grade prime coking coal, (iii) Blending with carbonaceous materials and (iv) mixing inorganic/organic binder. Hydrogenation of coal requires high temperature $\left(300\right.$ to $\left.700^{\circ} \mathrm{C}\right)$ and pressure (3 to $20 \mathrm{MPa}$ ) for its reaction. By this method, noncoking coal is structurally changed to coking coal which then can be used for coke making. Non-coking coal can be blended with prime coking coal to produce coal blend which could be used for making good quality coke. Another way of utilizing non-coking coal is by blending it with carbonaceous materials such as pitch, waste plastics, molasses, sawdust, coconut shell, etc. to improve the hydrogen content and plasticity of coal.

\section{Environmental Issues}

Coal mining and thermal power plants significantly impact the local environment. Furthermore, mining operations affect land, water, forests and habitats. Key environmental concerns in the coal-power sector in India include:

- $\quad$ Flue gas emissions-particulates, sulphur oxides (SOx), nitrous oxides (NOx), and other hazardous chemicals;

- Pollution of local streams, rivers and groundwater from effluent discharges and percolation of hazardous materials from the stored fly ash;

- Soil contamination due to storing of fly ash.

India is projected to need over $400 \mathrm{GW}$ (Gigawatt), by 2030 which is nearly same as the current installed energy capacity of Japan, South Korea and Australia combined. As a result, India will become the world's third largest $\mathrm{CO}_{2}$ emitter by 2015 . A global roadmap for the new low carbon economy, investigates how global economic development can be achieved while avoiding dangerous climate change. This calls for zero emissions and coal technology. Low emissions coal technology is more costly than a traditional pulverized coal plant, and this along with other barriers prevent widespread implementation of such installations in India. Nonetheless, a two-pronged long-term strategy must be assessed: the reduction of fuel costs and emissions through efficiency gains and the removal of $\mathrm{CO}_{2}$ from the conversion process through its capture and storage. Clean coal technologies for improved efficiency of the conversion cycle is the need of the hour. Carbon capture and sequestration (CCS) is the critical enabling technology to reduce $\mathrm{CO}_{2}$ emissions significantly while allowing coal to meet world's pressing energy needs. Emission reductions can be achieved partly by the employment of coal technologies that improve on conventional steam-cycle power plants (Vorrias et al., 2013). With the current best available technique (BAT), energy conversion efficiency of coal-fired power plants is around $46 \%$ for hard coal plants and $43 \%$ for lignite plants. Improved combustion technologies include ultra-supercritical (USC), pressurized fluidized bed (PFB) and oxygen-rich combustion which are expected to improve efficiency above $50 \%$, possibly up to $60 \%$. For each of these, further effort is required 
to increase their scale, reduce costs and develop new materials. Crucially, CCS can only be applied postcombustion in such plants; and methods for adding this final step to the power plant without an undue efficiency penalty, still need to be demonstrated.

\section{Coal Gasification}

Coal gasification is a technology which is used to convert coal into gas for various applications such as production of synthetic natural gas, liquid fuels, gaseous fuels, hydrogen gas, etc. During coal gasification, coal reacts with high pressure steam and oxygen, to produce the gas (Vorrias et al., 2013). As Indian coal is associated with high clay minerals, direct run-offmines coal cannot be used for gasification. It leads to increase slag formation in the furnace and ultimately cause fouling of the syngas cooler. The coal needs to be beneficiated to remove the major portion of the clay minerals before its utilization. Besides, in order to improve coal gasification, better understanding of slag behaviour and the characteristics of the slagging process is needed. New power plants of the future will differ from conventional plants in significant ways. Here, the coal is converted into a fuel gas, and then thoroughly cleaned for burning in a manner similar to that used to burn natural gas. The first step is to capture the carbon dioxide created when coal is turned into a fuel gas. In the second stage, one of the components of the fuel gas, carbon monoxide, is mixed with water to produce hydrogen as fuel. In this process, emissions of conventional pollutants such as sulphur, soot and smog-forming nitrogen, will be extremely low. Coal cannot be called 'clean' until its $\mathrm{CO}_{2}$ emissions are captured and utilized/stored safely. The $\mathrm{CO}_{2}$ emission can be tackled by sequestration from coal-fired source such as power plants, coke ovens, blast furnace, etc. The separation of carbon dioxide mixed with methane from natural gas is wellproven. It may be mentioned here that capture of carbon dioxide from flue gas streams following combustion in air is much more difficult and expensive, as the carbon dioxide concentration is only about $14 \%$ at best.The carbon dioxide captured from a power plant can be injected into rock body at least a mile down along deep underground wells. It is routinely injected underground, but mostly into oil-bearing rocks, to force oil to the surface. Any project that aims at carbon dioxide capture from power plants will be a milestone for no reason other than to keep $\mathrm{CO}_{2}$ out of the atmosphere. Engineers and geologists must monitor the spread of carbon dioxide underground and find out a suitable solution to neutralize its adverse effect.

\section{Fly Ash}

Fly ash is the finest coal combustion residue (CCR) generated due to the transformation of mineral matter present in coal particles during combustion. Indian coals have very high ash content. Coal with an ash content of around $40 \%$ and more is predominantly used in India for thermal power generation. As a consequence of its usage for power generation, a huge amount of fly ash is generated in thermal power plants, causing several disposal-related problems. The generation of fly ash is projected to increase to about $170 \mathrm{Mt}$ with increase in consumption of coal in power plants to a level of $500 \mathrm{Mt}$ by 2012. For disposal of $170 \mathrm{Mt}$ of fly ash, roughly 120,000 hectares of land will be needed. In India, the problem is further compounded by the use of wet fly ash collection systems by a large number of power plants, which results in degradation of the pozzolanic characteristics of the ash, an essential ingredient for several ashbased products. Thus in the coming years, fly ash disposal would be a major challenge unless adequate initiatives are undertaken by the thermal power plants to popularize commercial usage of fly ash. Presently, fly ash is being utilized for brick-making, land filling, construction purposes, soil amendment, etc. Major areas of fly ash utilization are (1) making of bricks/ blocks, cellular concrete products and lightweight aggregates, (2) manufacture of cement, (3) road construction and (4) embankment, backfill, land development, etc.At present, processes have been developed to use fly ash in building brick production by cold setting method. In this process, fly ash is reacted in presence of alkali activator to form hydrous alumino-silicate phases which develop binding property in the product both under atmospheric and curing conditions. This process has been established in pilot scale for manufacture of building bricks having crushing strength of $80-150 \mathrm{~kg} / \mathrm{cm}^{2}$ by using $80-90 \%$ 
fly ash and blocks having $150-300 \mathrm{~kg} / \mathrm{cm}^{2}$ crushing strength containing $50-60 \%$ fly ash by weight. Fly ash is also used for production of sintered aggregates which requires about one ton of fly ash per ton of aggregate. The sintered fly ash aggregate pellet is produced in accordance with the specification of natural aggregate (IS: 383-1970) that ranges from 4 to $20 \mathrm{~mm}$ in size. The sintered lightweight aggregate is suitable for application in making low density concrete, sub base road and other building material products (Muduli et al., 2014). Mineral carbonation is a thermodynamically stable process for trapping of atmospheric $\mathrm{CO}_{2}$ where materials rich in alkaline earth metals $(\mathrm{Ca}, \mathrm{Mg}$, and $\mathrm{Fe})$ combine with $\mathrm{CO}_{2}$ to form stable carbonates. Fly ash is a potential source for mineral carbonation by proper chemical co-ordination to capture atmospheric $\mathrm{CO}_{2}$. The carbonated material can find application as a substrate and soil conditioner for agriculture (Muduli et al., 2010).

\section{Conclusions}

Coal will continue to be the principal source of energy

\section{References}

Atesok G, Yildrim I and Celik M S (1993) Applicability of the Reichert spiral for cleaning bituminous and lignitic coals: A pilot scale study Int J Miner Process 40 33-40

Cloke M, Barraza J and Miles N J ( 1997) Pilot-scale studies using a hydrocyclone and froth flotation for the production of beneficiated coal fractions for improved coal liquefaction Fuel 76 1217-1223

Crelling J C (2008) Applied Coal Petrology: The Role of Petrology in Coal Utilization Suárez - (Eds.Ruiz I and Crelling J C) pp 173-192, Academic Press USA

Das A, Sarkar B, Vidyadhar A, Singh A K and Bhattacharyya K K (2008a) A novel beneficiation scheme for a medium coking coal fines from India Int J Coal Prep Util 28 189200

Das B, Prakash S, Mishra B K and Reddy P S R (2008b) Enhancing the settling of coal washery tailings using synthetic polyelectrolytes and magnetite particles. In: Proceedings of the XXIV International Mineral Processing Congress (IMPC) Beijing, China, pp 1542-1548

Dey S, Paul G M and Pani S (2013) Flotation behavior of in India. Production of quality coal for power plants, metallurgical and cement industries, and other industrial use is a growing challenge. Therefore, the beneficiation of high ash coal will play a vital role in the days to come. The role of beneficiation is quite important, particularly in the context of non-coking coal, due to its complex nature that necessitates adoption of advanced technologies and processes to achieve the desired ash content at acceptable yield. Processes such as flotation, enhanced gravity separation, dewatering, blending, etc., must be given due importance. Furthermore, coking coal production in India must be reconsidered. India has very limited reserves of coking coal which is a key raw material for production of steel and other metallurgical goods. Hence, a concerted research effort must be directed to use non-coking coal after convertingit into coke.

\section{Acknowledgements}

Authors would like to acknowledge the support of A Tripathy, R K Dwari, S Mohanta, S Muduli and S S Rath, in preparing this manuscript.

weathered coal in mechanical and column flotation cell Powder Technol 246 689-694

Dwari R K, Mohanta S K, Rout B, Soni R K, Reddy P S R and Mishra B K (2015) Studies on the effect of electrode plate position and feed temperature on the tribo-electrostatic separation of high ash Indian coking coal, Adv Powder Technol 26 31-41

Dwari R K and Hanumantha Rao K (2008) Non-coking coal preparation by novel tribo-electrostatic method Fuel $\mathbf{8 7}$ 3562-3571

Dwari R K and Hanumantha Rao K (2006) Tribo-electrostatic behaviour of high ash non-coking Indian thermal coal Int J Miner Process 8 193-104

Future of coal electricity in India and sustainable alternatives, Aresearch report,World Institute of Sustainable Energy, Pune, (2013) http://wisein.org/WISE_Projects/final_coal_ report.pdf

Hacifazlioglu H (2012) Application of the modified water-only cyclone for cleaning fine coals in a Turkish washery, and comparison of its performance results with those of spiral and flotation Fuel Process Tech 102 11-17

Iwaro J and Mwasha A (2010) Towards energy sustainability in 
the world: the implications of energy subsidy for developing countries Int J Energy Environ 1 705-714

Internal Report (2015) Mp/GAP-220/May/2015, submitted to Ministry of Steel, Govt. of India, New Delhi, Development of technology to produce clean coal from high ash and high sulphur Indian coal

Jena M S, Biswal S K, Das S P and Reddy P S R (2008) Comparative study of the performance of conventional and column flotation when treating coking coal fines Fuel Process Technol 89 1409-1415

Jonathan P Mathews and Alan L Chaffee (2012) The molecular representations of coal - A review Fuel 96 1-14

Mathur R, Chand S and Tezuka T (2003) Optimal use of coal for the power generation in India Energy Policy 31 319-331

Mohanta S, Mishra B K and Biswal S K (2010) An emphasis on optimum fuel production for Indian coal preparation plants treating multiple coal sources Fuel 89 775-781

Mohanta S, Mishra B K, Chakraborty S and Meikap B C (2012) Cost and quality optimization: A win-win scenario for coal washery and thermal power plant Miner Process Ext Met Rev 33 280-291

Muduli S D, Nayak B D, Dhal N K and Mishra B K (2014) Atmospheric $\mathrm{CO}_{2}$ sequestration through mineral carbonation of fly ash Greener J Phys Sci 42 73-278

Muduli S D, Nayak B D, Rout P K, Pany S, Mustakim S M and Mishra B K (2010) Innovative process in manufacture of cold setting building brick from mining and industrial waste Indian Min Eng J 47 127-130

Panda L, Sahoo A K, Tripathy A, Biswal S K and Sahu A K (2012) Application of artificial neural network to study the performance of jig for beneficiation of non-coking coal Fuel 97 151-156

SahuA K, Biswal S K, Parida A, Reddy P S R and Misra V N (2005) A study of dynamic stability of medium in fluidized bed separator IIM Trans (India) 56 103-107

Sastry S R S, Reddy P S R, Bhattacharyya K K, Kumar S G and Narasimhan K S (1988) Miner Eng 1359-363

Singh R K and Das A (2013) Analysis of separation response of Kelsey centrifugal jig in processing fine coal Fuel Process Technol 115 71-78

Statistical review of world energy (2013) bp.com/statistical review, Coal Mining \& Quarrying, ttp://mospi.nic.in/mospi_new/ upload/Infra_stat_2010/6.\%20ch_coal.pdf

The energy policy of India, http://en.wikipedia.org/wiki/ Energy_policy_of_India

Trombley D and Kissock K (2007) Economics of energy efficiency in a carbon constrained world ACEEE Summer Study on Energy Efficiency in Industry, New York, July 24-27

Xia W, Yang J and Liang C (2013) Effect of microwave pretreatment on oxidized coal flotation, Powder Tech 237 186-189. 